Article

\title{
Modified Aminoglycosides Bind Nucleic Acids in High-Molecular-Weight Complexes
}

\author{
Lanqing Ying ${ }^{1}$, Hongkun Zhu ${ }^{1}$, Marina Y. Fosso ${ }^{2}$, Sylvie Garneau-Tsodikova ${ }^{2}$ (]) \\ and Kurt Fredrick 1,* \\ 1 Department of Microbiology and Center for RNA Biology, The Ohio State University, \\ Columbus, OH 43210-1292, USA; lqying567@gmail.com (L.Y.); hongkun.zhu@gmail.com (H.Z.) \\ 2 Department of Pharmaceutical Sciences in the College of Pharmacy, University of Kentucky, \\ Lexington, KY 40536-0596, USA; marina.fosso@uky.edu (M.Y.F.); sylviegtsodikova@uky.edu (S.G.-T.) \\ * Correspondence: fredrick.5@osu.edu; Tel.: +1-614-292-6679
}

Received: 6 February 2020; Accepted: 18 February 2020; Published: 21 February 2020

check for updates

\begin{abstract}
Aminoglycosides represent a large group of antibiotics well known for their ability to target the bacterial ribosome. In studying 6"-substituted variants of the aminoglycoside tobramycin, we serendipitously found that compounds with $C_{12}$ or $C_{14}$ linear alkyl substituents potently inhibit reverse transcription in vitro. Initial observations suggested specific inhibition of reverse transcriptase. However, further analysis showed that these and related compounds bind nucleic acids with high affinity, forming high-molecular weight complexes. Stable complex formation is observed with DNA or RNA in single- or double-stranded form. Given the amphiphilic nature of these aminoglycoside derivatives, they likely form micelles and/or vesicles with surface-bound nucleic acids. Hence, these compounds may be useful tools to localize nucleic acids to surfaces or deliver nucleic acids to cells or organelles.
\end{abstract}

Keywords: tobramycin; kanamycin; RNA; DNA; reverse transcriptase

\section{Introduction}

Aminoglycosides represent a group of structurally diverse amino-modified polysaccharides that are well known for their broad-spectrum activity against bacteria. Most aminoglycosides are structurally similar and share a central 2-deoxystreptamine ring. These compounds (henceforth abbreviated "AGs") bind helix h44 of 16S ribosomal RNA (rRNA) and inhibit protein synthesis [1,2], leading to bacterial cell death. AGs also interact with a number of other RNA targets. These include secondary rRNA sites [3], natural riboswitches [4], group I introns [5], and several retroviral RNA elements [6-9]. Binding stems from the ability of these positively-charged amino-rich AGs to form electrostatic interactions with the negatively-charged phosphate groups of the RNA [10], and to a lesser extent from hydrogen bonding involving the amino and hydroxyl groups of AGs [11]. The conformation of AGs along with the size of the interior loop of the target RNAs also influence the binding affinity $[12,13]$.

In addition to RNA, AGs have been shown to target certain proteins. AG-arginine conjugates (semi-synthetic AGs in which L-arginine moieties are attached to parent AGs) have been shown to prevent HIV-1 Tat protein from binding the transactivation responsive element [14] or interacting with gp41 and gp120 proteins $[15,16]$. These compounds have also been shown to inhibit early stages of the virus life cycle $[17,18]$.

\section{Results}

\subsection{Potent Inhibition of Reverse Transcriptase by Certain Aminoglycoside Variants}

Using the toeprinting technique [19] to study the effects of various 6"-thioether tobramycin (TOB) derivatives on ribosomal translocation [20], we were surprised to observe no primer extension products 
in some reactions. This suggested inhibition of avian myeloblastosis virus (AMV) reverse transcriptase (RT) by some of these compounds (Figure 1), which was confirmed in subsequent experiments (Figure 2). Those TOB derivatives with clear inhibitory activity have naphthyl or linear alkyl $\left(\mathrm{C}_{10}-\mathrm{C}_{22}\right)$ moieties, and the most potent inhibitors (termed TOB-C 12 and TOB- $C_{14} ; I_{50}$ values $\sim \mu \mathrm{M}$ ) bear $\mathrm{C}_{12}$ and $\mathrm{C}_{14}$ linear alkyl groups.

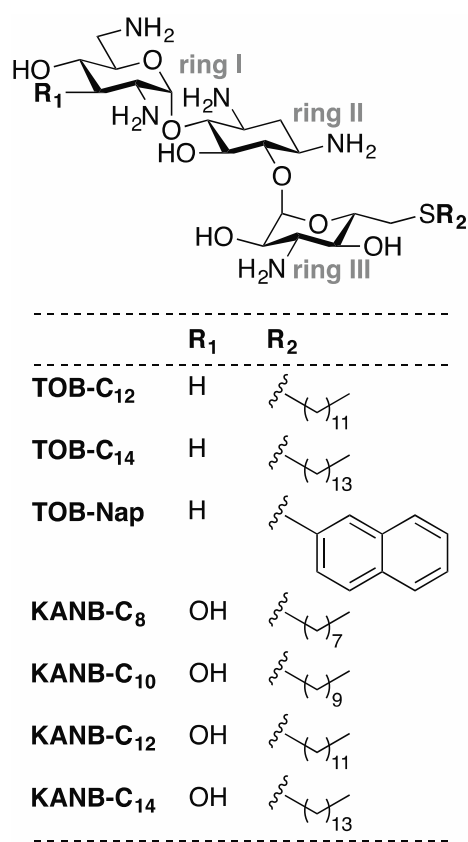

Figure 1. Compounds analyzed in this study. Related aminoglycosides TOB and KANB were modified with various 6 "-thioether substituents to generate the compounds shown. Derivatives of TOB (TOB- $\mathrm{C}_{12}$, TOB-C $_{14}$, TOB-Nap) and KANB (KANB-C 8, KANB-C 10, KANB-C $_{12}$, KANB-C $_{14}$ ) differ chemically at two positions $\left(\mathrm{R}_{1}\right.$ and $\left.\mathrm{R}_{2}\right)$ as indicated.

A

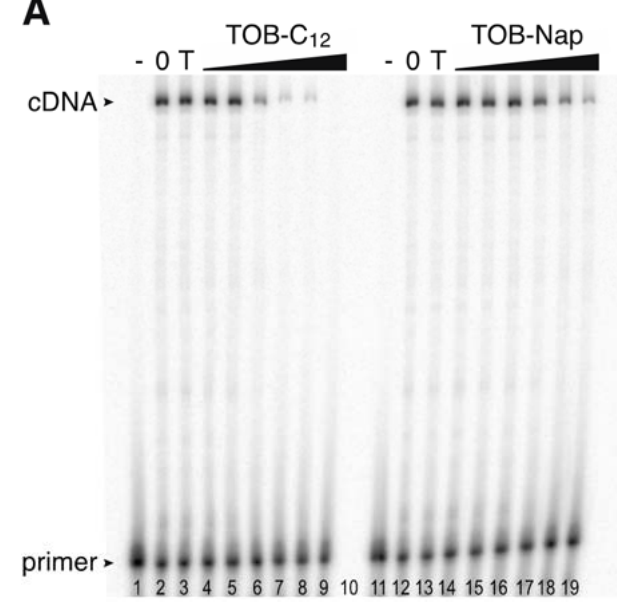

B

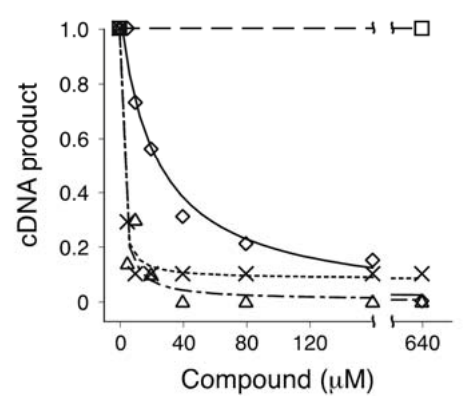

Figure 2. TOB variants inhibit AMV RT. (A) An experiment measuring primer extension in the presence and absence of TOB derivatives. Radiolabeled oligonucleotide primer was annealed to an RNA template and added to AMV RT and dNTP substrates in the absence (" 0 " lanes 2 and 12) or presence of TOB ("T" lanes 3 and 13; $1000 \mu \mathrm{M}$ ) or its derivatives (TOB-C $\mathrm{C}_{12}$, TOB-Nap; increasing concentrations as indicated). A control reaction lacking RT ("-" lanes 1 and 11) was included. Following incubation for $10 \mathrm{~min}$ at $37^{\circ} \mathrm{C}$, reaction products were resolved by PAGE. (B) The relative amount of full-length cDNA product was plotted as a function of compound concentration $\left(\square\right.$, TOB; $\triangle$, TOB- $C_{12} ; \times$, TOB- $C_{14} ; \diamond$, TOB-Nap), and the data were fit to a modified dose-response equation to obtain $\mathrm{IC}_{50}$ values (TOB- $\mathrm{C}_{12}, 1.6 \mu \mathrm{M}$; TOB-C ${ }_{14}, 1.1 \mu \mathrm{M}$; TOB-Nap, $23 \mu \mathrm{M}$ ). 
Reverse transcriptases share structural similarity to the single-subunit polymerases of bacteriophage T7 [21-24]. To assess specificity, we tested the effects of these compounds on Sequenase, an engineered version of T7 DNA polymerase lacking $3^{\prime}$-to-5' exonuclease activity. These compounds did inhibit Sequenase, albeit with $\mathrm{IC}_{50}$ values 50 -fold greater than those observed for RT (data not shown). We also looked at transcription by T7 RNA polymerase and found no apparent inhibition by these compounds (data not shown). Hence we inferred, at the time, that these compounds targeted DNA polymerases, especially RT.

We purified wild-type (WT) and two mutant versions of HIV-1 RT and tested their susceptibility to inhibition by the TOB derivatives (Figure 3, Table 1). Substitution K103N and Y181C each confers resistance to multiple non-nucleoside reverse transcriptase inhibitors (NNRTIs) and are among the most frequently isolated NNRTI-resistant mutations [25]. As expected, nevirapine (NVP, a well-known NNRTI) strongly inhibited the WT enzyme $\left(\mathrm{IC}_{50}=0.3 \mu \mathrm{M}\right)$ and had a much smaller impact on the $\mathrm{K} 103 \mathrm{~N}\left(\mathrm{IC}_{50}=180 \mu \mathrm{M}\right)$ or $\mathrm{Y} 181 \mathrm{C}$ variants $\left(\mathrm{IC}_{50}=200 \mu \mathrm{M}\right)$. The TOB derivatives TOB-C $\mathrm{C}_{12}, \mathrm{TOB} \mathrm{C}_{14}$, and TOB-Nap strongly inhibited HIV-1 RT, with $\mathrm{IC}_{50}$ values ranging from 0.3 to $40 \mu \mathrm{M}$ (Table 1 ). Inhibition by these compounds was virtually unaffected by K103N or Y181C, suggesting a mechanism distinct from that of NNRTIs.
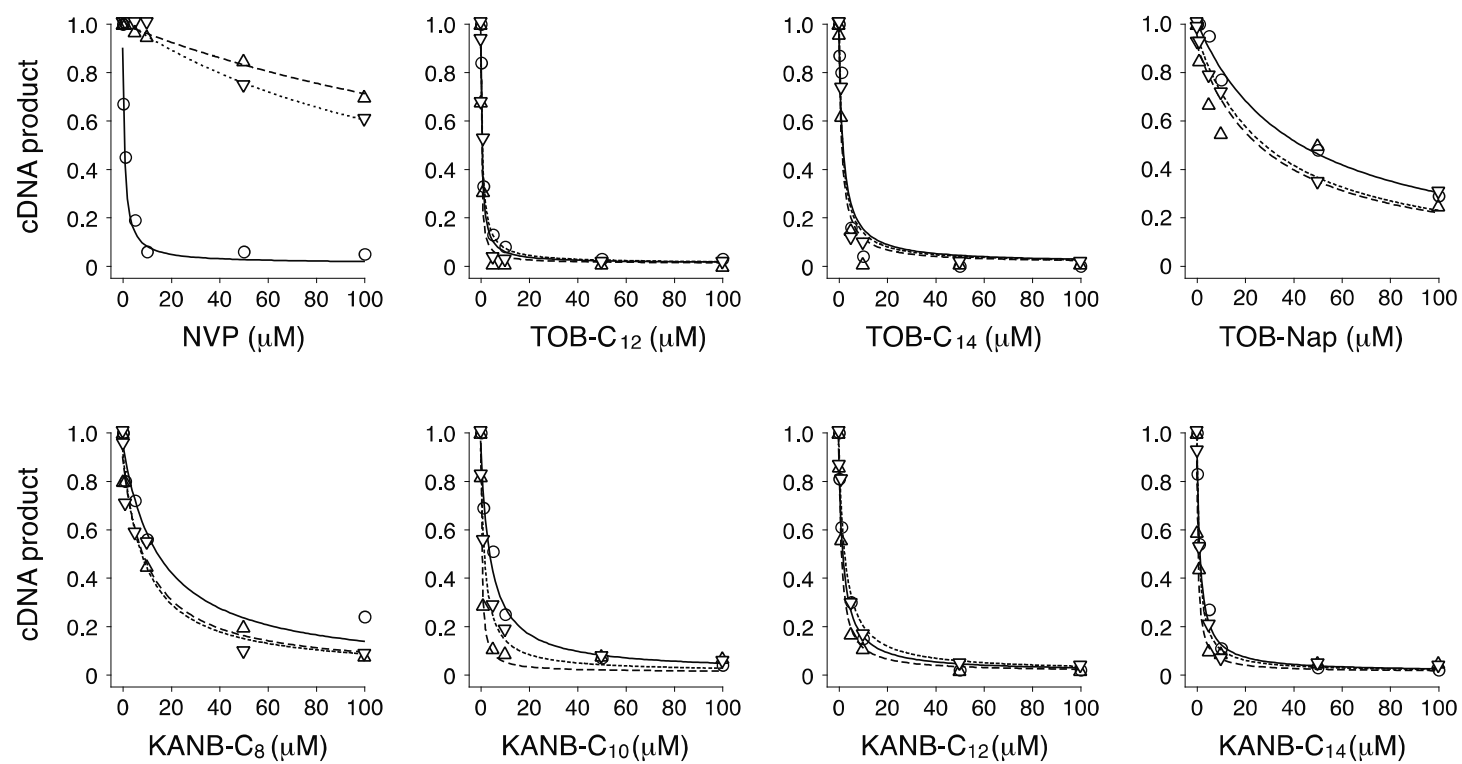

Figure 3. Modified aminoglycosides are potent inhibitors of wild-type (WT) and NNRTI-resistant HIV-1 RT. Effects of various compounds (as indicated) on the yield of cDNA product in primer extension reactions containing WT $(\bigcirc), \mathrm{K} 103 \mathrm{~N}(\nabla)$, or Y181C $(\triangle)$ RT enzymes. Data were fit to a modified dose-response equation to obtain the values shown in Table 1.

Table 1. Inhibition of WT and mutant HIV-1 RT by various compounds.

\begin{tabular}{cccc}
\hline \multirow{2}{*}{ Compounds } & \multicolumn{3}{c}{ IC $_{\mathbf{5 0}}(\boldsymbol{\mu M})$} \\
\cline { 2 - 4 } & WT & K103N & Y181C \\
\hline NVP & $0.3 \pm 0.2$ & $180 \pm 40$ & $200 \pm 30$ \\
TOB-C $_{12}$ & $0.3 \pm 0.1$ & $0.6 \pm 0.1$ & $0.5 \pm 0.1$ \\
TOB-C $_{14}$ & $1.9 \pm 0.3$ & $1.2 \pm 0.6$ & $1.4 \pm 0.4$ \\
TOB-Nap & $40 \pm 5$ & $40 \pm 11$ & $12 \pm 4$ \\
KANB-C $_{8}$ & $8 \pm 3$ & $7 \pm 1$ & $8 \pm 2$ \\
KANB-C $_{10}$ & $3.8 \pm 0.3$ & $1.9 \pm 0.3$ & $1.0 \pm 0.6$ \\
KANB-C $_{12}$ & $1.9 \pm 0.3$ & $2.0 \pm 0.2$ & $0.5 \pm 0.3$ \\
KANB-C $_{14}$ & $1.0 \pm 0.1$ & $0.9 \pm 0.1$ & $0.7 \pm 0.3$ \\
\hline
\end{tabular}

Data represent the mean \pm SEM from 3 or more independent experiments. 
We made analogous derivatives of kanamycin B (KANB), an AG structurally similar to TOB, and tested their activities against HIV-1 RT. There is a single chemical difference between KANB and TOB in ring I: KANB has a $3^{\prime}$-hydroxyl group $\left(\mathrm{R}_{1}=\mathrm{OH}\right)$, whereas TOB is devoid of a substituent at this position $\left(\mathrm{R}_{1}=\mathrm{H}\right)$ (Figure 1). Four derivatives of KANB were analyzed, with 6"-linear alkyl substituents $\left(\mathrm{C}_{8}, \mathrm{C}_{10}, \mathrm{C}_{12}\right.$, and $\left.\mathrm{C}_{14}\right)$. All four of these compounds inhibited HIV-1 RT, with $\mathrm{IC}_{50}$ values ranging from 0.5 to $8.0 \mu \mathrm{M}$ (Figure 3 and Table 1). Neither K103N nor Y181C conferred resistance to these compounds, as indicated by equivalent or slightly smaller $\mathrm{IC}_{50}$ values. These data are highly similar to those obtained for the TOB derivatives, indicating that the chemical difference in ring I has essentially no influence on inhibitory activity.

The experiments above involved multiple-nucleotide extension of a primer annealed to an RNA (or DNA) template. To further investigate the basis of inhibition, we analyzed the kinetics of single-nucleotide incorporation (Figure 4$)$. In the absence of inhibitor, the observed rate $\left(k_{\mathrm{obs}}\right)$ of adenosine monophosphate addition by AMV RT increased with dATP concentration, yielding a $K_{\mathrm{M}(\mathrm{dATP})}$ value of $\sim 2 \mu \mathrm{M}$ (Figure $4 \mathrm{~B}$ ). Inclusion of TOB-C 12 with $\mathrm{RT}$ and primer:template prior to rapid mixing with $\mathrm{dATP}$ reduced the amplitude of the reaction without affecting the rate (Figure $4 \mathrm{C}$ ). The amplitude of the reaction decreased as function of TOB- $\mathrm{C}_{12}$ concentration, yielding under these conditions $\mathrm{IC}_{50}$ values of $13 \mu \mathrm{M}$ and $17 \mu \mathrm{M}$ for reactions containing $\mathrm{dATP}$ at $10 \mu \mathrm{M}$ or $150 \mu \mathrm{M}$, respectively (Figure 4D). The fact that only amplitude was reduced suggests that binding of TOB-C 12 completely blocks nucleotide incorporation in some way.
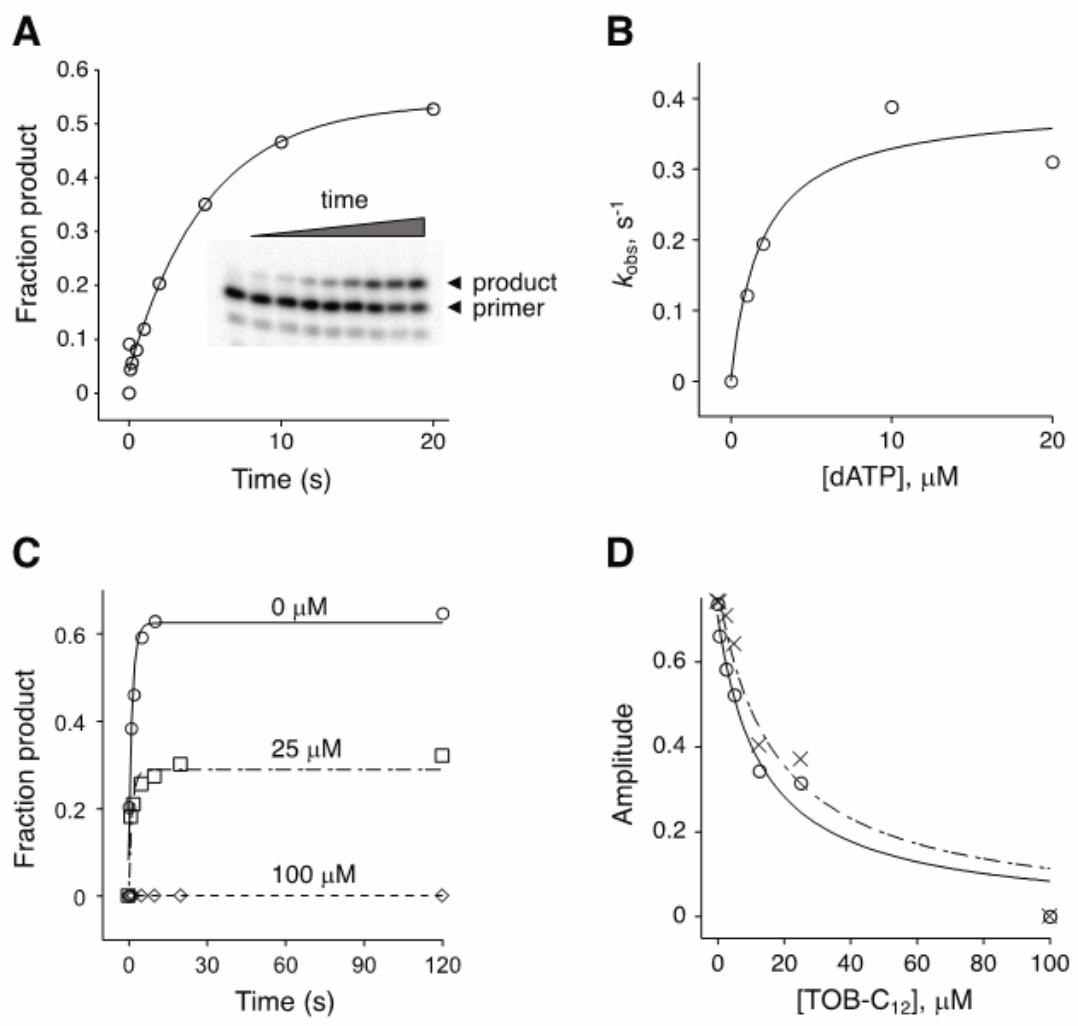

Figure 4. Effect of TOB- $\mathrm{C}_{12}$ on the kinetics of single-nucleotide incorporation by AMV RT. (A) Example of an experiment measuring the rate of adenosine monophosphate incorporation by AMV RT upon addition of dATP $(2 \mu \mathrm{M})$. Primary data (inset) were quantified, plotted versus time, and fit to a single-exponential function to obtain the observed rate $\left(k_{\mathrm{obs}}\right)$. (B) A secondary plot of $k_{\mathrm{obs}}$ versus dATP concentration suggests a $K_{\mathrm{M}}(\mathrm{dATP})$ of $\sim 2 \mu \mathrm{M}$. (C) Primer:template was incubated with or without TOB- $\mathrm{C}_{12}$ prior to rapid mixing with $\mathrm{dATP}(150 \mu \mathrm{M})$ and quenching at various times. Time courses of product formation in the absence $(\bigcirc)$ or presence $(\square, 25 \mu \mathrm{M} ; \diamond, 100 \mu \mathrm{M})$ of TOB-C 12 are shown. (D) Amplitude was measured as a function of TOB- $\mathrm{C}_{12}$ concentration, in reactions containing $10 \mu \mathrm{M}(\bigcirc)$ or $150 \mu \mathrm{M}(\mathrm{X}) \mathrm{dATP}$. 


\subsection{AG variants Bind Nucleic Acids in High-Molecular-Weight Complexes}

AGs are well known to bind RNA, raising the possibility that these compounds act by targeting the template or primer:template rather than RT. Our first clue that this was the case came from observation that nucleic acid "competitor" substantially reduced the degree of inhibition. A four-fold excess of competitor oligonucleotide $(2 \mu \mathrm{M})$ over primer-annealed template $(0.5 \mu \mathrm{M})$ increased the $\mathrm{IC}_{50}$ from $2.7 \mu \mathrm{M}$ to $5.7 \mu \mathrm{M}$ in a conventional primer extension assay of AMV RT (data not shown). Order-of-addition experiments provided further evidence that these AG compounds target the primer:template. An example of one such experiment, involving single-nucleotide incorporation by HIV-1 RT, is shown in Figure 5A. When TOB- $\mathrm{C}_{12}$ was preincubated with primer:template in the absence of RT, no detectable product was seen upon combining the remaining components (lanes 6 and 8). On the other hand, preincubation of TOB- $\mathrm{C}_{12}$ with RT hindered product formation to a lesser degree (lanes 5 and 7).
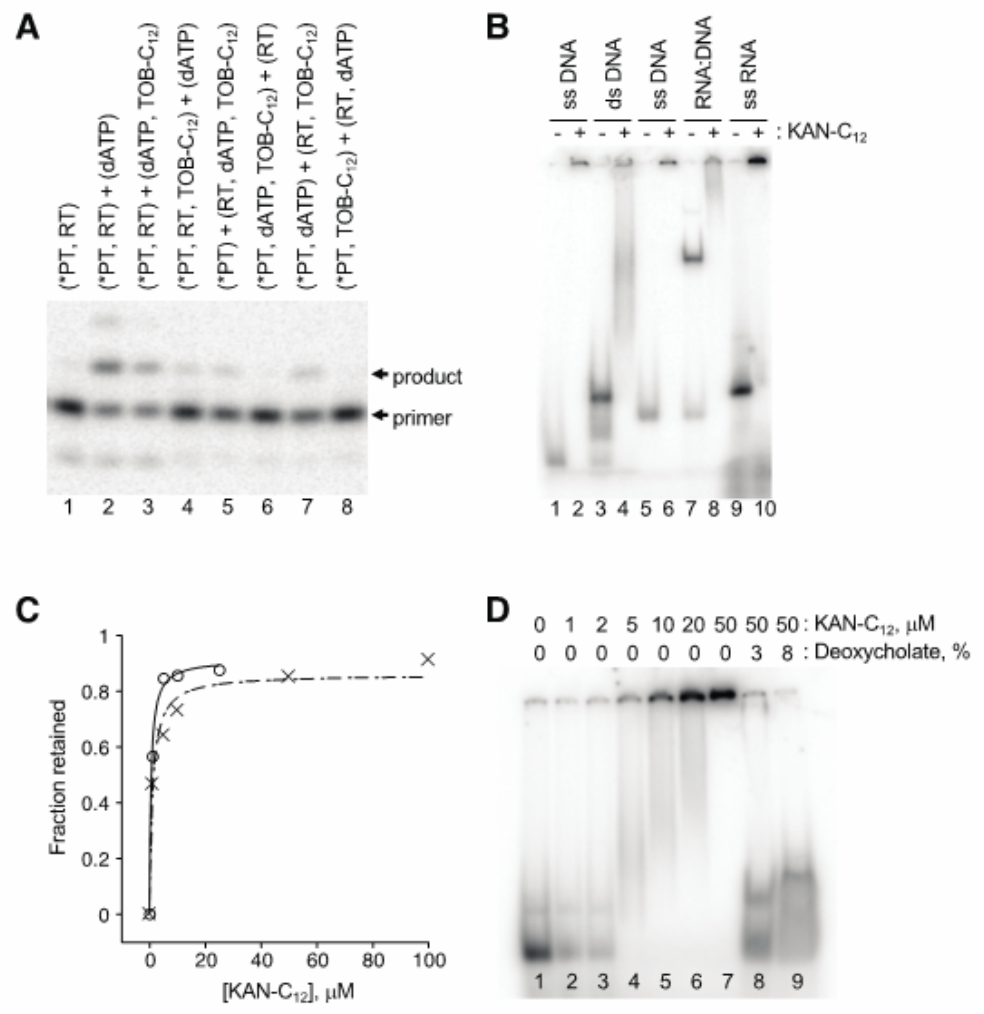

Figure 5. Modified aminoglycosides bind nucleic acids in high-molecular-weight complexes. (A) Preincubation of TOB- $\mathrm{C}_{12}$ with primer:template duplex results in the largest degree of inhibition. Components of the single-nucleotide primer-extension reaction (radiolabeled primer annealed to RNA template, *PT; HIV-1 reverse transcriptase, RT; dATP; TOB- $\mathrm{C}_{12}$ ) were pre-equilibrated in separate tubes (denoted by parentheses) for $20 \mathrm{~min}$ at $37^{\circ} \mathrm{C}$ and then combined (as indicated) and further incubated for 1 min prior to PAGE analysis. (B) Gel-shift experiments show that $\mathrm{KAN}-\mathrm{C}_{12}$ forms high-molecular weight complexes with various nucleic acids. A radiolabeled DNA oligonucleotide (18mer, lanes $1-4 ; 22$ mer, lanes 5-8), alone or pre-annealed to a complementary strand (as indicated), or an RNA oligonucleotide (25mer, lanes 9-10), was incubated with or without $\mathrm{KAN} \mathrm{C}_{12}(150 \mu \mathrm{M})$ for $15 \mathrm{~min}$ at $25^{\circ} \mathrm{C}$ (as indicated) and then subjected to native PAGE. (C) Experiments with ultrafiltration devices show that RNA or DNA oligonucleotides form large and stable complexes. Radiolabeled oligonucleotide (DNA, O; RNA, $\mathrm{X}$ ) was incubated with $\mathrm{KAN}-\mathrm{C}_{12}$ (various concentrations) and the fraction in complexes of $>300 \mathrm{kDa}$ was determined by ultrafiltration (300 kDa MWCO). Data were plotted and fit to the equation $\mathrm{y}=\left(\mathrm{y}_{\max } \cdot \mathrm{x}\right) /\left(K_{\mathrm{D}}+\mathrm{x}\right)$ to yield apparent $K_{\mathrm{D}}$ values $(0.6 \mu \mathrm{M}, 1.1 \mu \mathrm{M})$. (D) Ionic detergents disrupt complexes. A radiolabeled RNA oligonucleotide was incubated with $\mathrm{KAN}-\mathrm{C}_{12}$ (various concentrations, as indicated), and complexes formed at $50 \mu \mathrm{M} \mathrm{KAN}-\mathrm{C}_{12}$ were subsequently incubated with deoxycholate (as indicated) prior to native PAGE analysis. 
Gel mobility shift experiments demonstrated that these AG variants bind nucleic acids, forming high-molecular-weight complexes (Figure 5B). When a radiolabeled 18 mer DNA oligonucleotide was preincubated with KANB-C $12(100 \mu \mathrm{M})$ and subjected to native gel electrophoresis, all signal was shifted to the well, with no band corresponding to free oligonucleotide (compare lanes 1 and 2). A DNA duplex, formed by annealing the 18mer to a 31mer, migrated more slowly through the gel (lane 3). Preincubation with KANB-C 12 resulted in loss of this band, with signal shifted higher in the gel and/or in the well (lane 4). Similar results were seen when other oligonucleotides were tested, including an RNA oligonucleotide (Figure 5B, lanes 5-10).

Next, we used ultrafiltration devices to further evaluate the stability and nature of these complexes. Radiolabeled DNA or RNA oligonucleotide was incubated with KANB-C 12 (various concentrations), and the amount of nucleic acid able to pass through the porous membrane was quantified. The fraction of retained (bound) oligonucleotide increased sharply as a function of $\mathrm{KANB}_{12}$, yielding binding curves with $K_{\mathrm{D}}$ values of $\sim 1 \mu \mathrm{M}$ (Figure $5 \mathrm{C}$ ), reminiscent of the $\mathrm{IC}_{50}$ values reported above for the same compound (Table 1). Devices with molecular weight cut off (MWCO) of $30 \mathrm{kDa}$ or $300 \mathrm{kDa}$ gave virtually identical results, indicating large complexes, consistent with the gel mobility shift data above. Analogous experiments performed with duplex DNA or heteroduplex DNA:RNA yielded similar data with no indication of enhanced complex stability (data not shown).

The AG variants analyzed here are amphiphilic, raising the possibility that they form micelles and/or bilayer vesicles in aqueous solution, which bind nucleic acids on their surfaces. In line with this hypothesis, ionic detergents such as SDS and deoxycholate readily disrupted these complexes (Figure 5D), whereas high concentrations of urea, guanidine, $\mathrm{KCl}$, or EDTA had little or no impact.

\section{Discussion}

Here, we report the serendipitous finding that $A G$ variants bearing $C_{12}$ or $C_{14}$ linear alkyl substituents are potent inhibitors of RT. These compounds act by binding nucleic acids with high affinity, forming high-molecular weight complexes. Given the amphiphilic nature of these AG derivatives, we suspect that they form micelles and/or vesicles with surface-bound nucleic acids. In line with this view, the complexes dissociate when challenged with ionic detergents.

Natural AGs have highest affinity for the narrow major groove of A-form RNA and exhibit progressively lower affinity for nucleic acid duplexes as the major groove width increases [26]. Our modified AGs bind similarly to DNA or RNA, in single- or double-stranded form, implying a helix-independent mode of binding. In either a micelle or vesicle, the hydrophilic surface would present an array of AG moieties. We envision that multiple interactions between the positively-charged amino groups on this surface and the negatively-charged phosphates on the nucleic acid backbone results in the tight and nonspecific overall binding that we observe.

Early on in this work, we mistakenly deduced that these compounds targeted RT, because other polymerases appeared less susceptible or resistant to these compounds. Why potent inhibition was only seen in the RT assays remains unclear. This might be due to differences in experimental conditions or distinct abilities of the polymerases to compete for primer: template. In any event, it is clear that these AG variants bind nucleic acids and thereby inhibit RT.

Our findings may hold particular relevance in the realms of biotechnology and chemical engineering. These AG derivatives could be useful for localizing nucleic acids to surfaces or delivering nucleic acids to cells or cellular compartments. Indeed, independent studies by Pitard, Lehn, and coworkers have shown that analogous molecules containing an AG head group linked either to cholesterol or dual aliphatic chains (e.g., $C_{18}$ ) can be used to deliver nucleic acids into cells [27-29]. Such designer molecules form various high-order structures with DNA or RNA in vitro, which efficiently transfect diverse cell lines with plasmid DNA, mRNA, or siRNA. A deeper understanding of the unique chemical and biophysical properties of these compounds may lead to new applications or improved technologies down the road. 


\section{Materials and Methods}

\subsection{Biochemical Reagents}

Plasmids pET-RT66 and p6H-RT51, which overexpress HIV-1 RT subunits p66 and His 6 -tagged p51, were generously provided by Samuel Wilson (NIH). Mutations K103N and Y181C were each introduced into pET-RT66 using QuikChange ${ }^{\mathrm{TM}}$ mutagenesis. Subunits p66 and His 6 -p51 were overproduced in E. coli strains BL21/DE3 and DH5 $\alpha$, respectively, and the RT heterodimer (WT or mutant forms) was reconstituted in mixed lysates and purified essentially as described [30]. Each overexpression strain was grown in LB medium with appropriate antibiotics at $37^{\circ} \mathrm{C}$ until the culture reached an $\mathrm{OD}_{600}$ of 0.6 , IPTG $(0.5 \mathrm{mM})$ was added, and the culture was further incubated for $3.5 \mathrm{~h}$ to allow ample protein production. Cells (from $4 \mathrm{~L}$ culture) were pelleted and stored at $-20{ }^{\circ} \mathrm{C}$. All subsequent steps were performed at $4{ }^{\circ} \mathrm{C}$. Each cell pellet was resuspended in $20 \mathrm{~mL}$ buffer A [50 mM Tris- $\mathrm{HCl}(\mathrm{pH} 7.9)$, $60 \mathrm{mM} \mathrm{NaCl}, 10 \%$ glycerol, $1 \mathrm{mM} \beta \mathrm{ME}$, and protease inhibitors (Protease Inhibitor Cocktail, Roche Diagnostics)], and the cells were lysed using a French Press. The lysate was clarified by centrifugation at $5900 \mathrm{~g}$ for $15 \mathrm{~min}$, and the protein concentration of each lysate was estimated using the Bradford assay. Based on these estimates, each p66 strain lysate was separately mixed with p51 strain lysate in a 3:1 ratio. Each mixture was passed through a Q-Sepharose column (2 mL, Bio-Rad), pre-equilibrated with buffer A, and the flow-through (containing HIV-1 RT) was collected. $\mathrm{NaCl}(0.5 \mathrm{M})$, imidazole $(10 \mathrm{mM})$, and $4 \mathrm{~mL}$ of His-Bind nickel column resin (Ni-NTA Agarose, QIAGEN) pre-equilibrated in buffer B [50 mM Tris-HCl (pH 7.9), $500 \mathrm{mM} \mathrm{NaCl}, 10 \mathrm{mM}$ imidazole, 10\% glycerol, and $1 \mathrm{mM} \beta \mathrm{ME}$ ] were added, and the mixture was rotated for $1 \mathrm{~h}$. The resin was poured into a column and washed with 10 column volumes (CV) of buffer B, $10 \mathrm{CV}$ of buffer C [50 mM Tris- $\mathrm{HCl}$ (pH 7.9), $1 \mathrm{M} \mathrm{NaCl}$, $10 \mathrm{mM}$ imidazole, $10 \%$ glycerol, and $1 \mathrm{mM} \beta \mathrm{ME}$ ], and $10 \mathrm{CV}$ of buffer D [50 mM Tris- $\mathrm{HCl}(\mathrm{pH} 7.9)$, $1 \mathrm{M} \mathrm{NaCl}, 15 \mathrm{mM}$ imidazole, $10 \%$ glycerol, and $1 \mathrm{mM} \beta \mathrm{ME}$ ]. Proteins were eluted from the column with an imidazole gradient $(10-500 \mathrm{mM})$ in buffer B. Fractions $(0.5 \mathrm{~mL})$ were collected, and DTT $(2 \mathrm{mM})$ and EDTA $(5 \mathrm{mM})$ were added to each fraction. Fractions were analyzed by SDS-PAGE, and those containing $\mathrm{p} 66$ and $\mathrm{p} 51$ at a 1:1 ratio were pooled. The RT was further purified using a FPLC RESOURCE S column (6 mL, GE Healthcare). The protein was bound to the column, washed with $10 \mathrm{CV}$ of buffer E [50 mM Tris- $\mathrm{HCl}$ (pH 6.5), $60 \mathrm{mM} \mathrm{NaCl}, 10 \%$ glycerol, and $1 \mathrm{mM} \beta \mathrm{ME}$ ], and eluted using a $\mathrm{NaCl}$ gradient. Fractions $(0.5 \mathrm{~mL})$ containing purified RT with p66 and p51 subunits at a 1:1 ratio were pooled, dialyzed against buffer $\mathrm{F}[50 \mathrm{mM}$ Tris- $\mathrm{HCl}$ (pH 7.5), $100 \mathrm{mM} \mathrm{NaCl}, 1 \mathrm{mM} \beta \mathrm{ME}$, and $10 \%$ glycerol], and stored at $-20{ }^{\circ} \mathrm{C}$.

Template RNA, based on T4 gene 32 [m291 or m292, [31]; most experiments] was made by in vitro transcription and PAGE purified. Primer (22 nt) complementary to the $3^{\prime}$-end of template RNA was $5^{\prime}$-end labeled using T4 polynucleotide kinase (NEB) and $\gamma-\left[{ }^{32} \mathrm{P}\right]$-ATP. AMV RT was purchased from Life Sciences Advanced Technologies, Inc. Sequenase was purchased from Affymetrix/Thermo Fisher Scientific. NVP (obtained from the NIH) was dissolved in DMSO. AG derivatives, synthesized as described previously [20,32], were dissolved in water.

\subsection{Primer Extension Assays}

To assay multi-nucleotide incorporation by RT, $5^{\prime}-\left[{ }^{32} \mathrm{P}\right]$-labeled primer $(\sim 0.05 \mu \mathrm{M})$ was annealed to mRNA $(0.33 \mu \mathrm{M}$, unless otherwise indicated), RT (HIV-1 or AMV; $32 \mathrm{nM})$ and the four deoxynucleotide triphosphates (dNTPs; $375 \mu \mathrm{M}$ each) in buffer G $\left[10 \mathrm{mM}\right.$ Tris- $\mathrm{HCl}$ (pH 7.5), $60 \mathrm{mM} \mathrm{NH}_{4} \mathrm{Cl}, 10 \mathrm{mM} \mathrm{MgCl}_{2}$, and $6 \mathrm{mM} \beta \mathrm{ME}$ ] were added, in the absence or presence of inhibitor (as indicated), and reactions were incubated at $37^{\circ} \mathrm{C}$ for $10 \mathrm{~min}$. An equal volume of stop buffer (95\% formamide, $20 \mathrm{mM}$ EDTA, 0.05\% xylene cyanol, and $0.05 \%$ bromophenol blue) was added, and products were analyzed by denaturing $7 \%$ PAGE. The relative amount of the full-length cDNA product (y) was plotted as a function of inhibitor concentration, and the data were fit to the modified dose response equation $\mathrm{y}=a+b /[1+(\mathrm{x} / c)]$ (with Hill coefficient of 1 ), where $a$ corresponds to background signal, $b$ is the maximal cDNA product observed, and $c$ is the $\mathrm{IC}_{50}$ value. 
Single-nucleotide incorporation by RT was measured using a quench-flow machine (KinTek RQF-3). Typically, $5^{\prime}-[32 \mathrm{P}]$-labeled primer $(<0.05 \mu \mathrm{M})$ was annealed to mRNA $(0.2 \mu \mathrm{M})$, equilibrated in buffer $\mathrm{H}$ [Tris- $\mathrm{HCl}$ ( $\mathrm{pH} 7.5), 80 \mathrm{mM} \mathrm{KCl}, 20 \mathrm{mM} \mathrm{MgCl} 2,2 \mathrm{mM} \mathrm{DTT]}$ with RT (AMV or HIV-1, as indicated) in the absence or presence of inhibitor (as indicated), and rapidly mixed with dATP (variable concentration, as indicated). Each reaction was quenched with 0.5 M EDTA at various time points; the data were plotted and fit to a single exponential equation to obtain observed rate and amplitude.

To assay Sequenase activity, two DNA oligonucleotides (5'-GGAATTCACTAGTTTGAAATGAAT GAAGCACTCTACTATATTCTTAATAGGTCC- $3^{\prime}$ and $5^{\prime}$-CGGGATCCATTTCTCGAGGGATATGATAG TCAAACAGGACCTATTAAG-3', $0.5 \mu \mathrm{M}$ each) with complementary $3^{\prime}$-ends were annealed in Sequenase buffer [40 mM Tris- $\mathrm{HCl}(\mathrm{pH} 7.5), 20 \mathrm{mM} \mathrm{MgCl}_{2}, 50 \mathrm{mM} \mathrm{NaCl}$. DTT (1 mM) and dNTPs ( $375 \mu \mathrm{M}$ each) were added, followed by inhibitor (as indicated, various concentrations) and Sequenase 2.0 ( $30 \mathrm{nM}$; USB). Reactions were incubated at $37^{\circ} \mathrm{C}$ for $10 \mathrm{~min}$, and DNA products were resolved by $7 \%$ denaturing PAGE and quantified. Data were analyzed as described above for the RT multi-nucleotide incorporation assay.

\subsection{Binding Experiments}

For binding reactions, components were incubated in buffer $\mathrm{H}$ at $25^{\circ} \mathrm{C}$ for $15 \mathrm{~min}$. The fraction of bound $5^{\prime}-\left[{ }^{32} \mathrm{P}\right]$-labeled nucleic acid was evaluated using native $6 \%$ PAGE or ultrafiltration devices (Nanosep Omega, PALL Life Sciences).

\section{Conclusions}

In this work, we show that $A G$ derivatives carrying $C_{12}$ or $C_{14}$ alkyl substituents are potent inhibitors of RT. These compounds act by binding nucleic acids in high-molecular-weight complexes. As these compounds are amphiphilic, they likely form micelles and/or vesicles with surface-arrayed AG moieties that interact favorably with the sugar-phosphate backbone of nucleic acid strands.

Author Contributions: Conceptualization, K.F.; Formal analysis, L.Y. and K.F.; Funding acquisition, S.G.-T. and K.F.; Investigation, L.Y. and H.Z.; Project administration, K.F.; Resources, M.Y.F. and S.G.-T.; Supervision, K.F.; Validation, L.Y.; Writing—original draft, L.Y., H.Z. and K.F.; Writing—review \& editing, M.Y.F., S.G.-T. and K.F. All authors have read and agreed to the published version of the manuscript.

Funding: This work was supported by grants from the National Institutes of Health (GM072528 to K.F. and AI090048 to S.G.-T.).

Acknowledgments: We thank S. Wilson for providing the constructs to overexpress and purify HIV-1 RT.

Conflicts of Interest: The authors declare no conflict of interest.

\section{References}

1. Carter, A.P.; Clemons, W.M.; Brodersen, D.E.; Morgan-Warren, R.J.; Wimberly, B.T.; Ramakrishnan, V. Functional insights from the structure of the $30 \mathrm{~S}$ ribosomal subunit and its interactions with antibiotics. Nature 2000, 407, 340-348. [CrossRef] [PubMed]

2. Ying, L.; Zhu, H.; Shoji, S.; Fredrick, K. Roles of specific aminoglycoside-ribosome interactions in the inhibition of translation. RNA 2019, 25, 247-254. [CrossRef] [PubMed]

3. Borovinskaya, M.A.; Pai, R.D.; Zhang, W.; Schuwirth, B.S.; Holton, J.M.; Hirokawa, G.; Kaji, H.; Kaji, A.; Cate, J.H. Structural basis for aminoglycoside inhibition of bacterial ribosome recycling. Nat. Struct. Mol. Biol. 2007, 14, 727-732. [CrossRef] [PubMed]

4. Jia, X.; Zhang, J.; Sun, W.; He, W.; Jiang, H.; Chen, D.; Murchie, A.I. Riboswitch control of aminoglycoside antibiotic resistance. Cell 2013, 152, 68-81. [CrossRef]

5. Von Ahsen, U.; Davies, J.; Schroeder, R. Antibiotic inhibition of group I ribozyme function. Nature 1991, 353, 368-370. [CrossRef]

6. Ennifar, E.; Paillart, J.C.; Marquet, R.; Ehresmann, B.; Ehresmann, C.; Dumas, P.; Walter, P. HIV-1 RNA dimerization initiation site is structurally similar to the ribosomal A site and binds aminoglycoside antibiotics. J. Biol. Chem. 2003, 278, 2723-2730. [CrossRef] 
7. Wang, S.; Huber, P.W.; Cui, M.; Czarnik, A.W.; Mei, H.Y. Binding of neomycin to the TAR element of HIV-1 RNA induces dissociation of Tat protein by an allosteric mechanism. Biochemistry 1998, 37, 5549-5557. [CrossRef]

8. Kumar, S.; Ranjan, N.; Kellish, P.; Gong, C.; Watkins, D.; Arya, D.P. Multivalency in the recognition and antagonism of a HIV TAR RNA-TAT assembly using an aminoglycoside benzimidazole scaffold. Org. Biomol. Chem. 2016, 14, 2052-2056. [CrossRef]

9. Wang, Y.; Hamasaki, K.; Rando, R.R. Specificity of aminoglycoside binding to RNA constructs derived from the 16S rRNA decoding region and the HIV-RRE activator region. Biochemistry 1997, 36, 768-779. [CrossRef]

10. Walter, F.; Vicens, Q.; Westhof, E. Aminoglycoside-RNA interactions. Curr. Opin. Chem. Biol. 1999, 3, 694-704. [CrossRef]

11. Jiang, L.; Patel, D.J. Solution structure of the tobramycin-RNA aptamer complex. Nat. Struct. Biol. 1998, 5, 769-774. [CrossRef] [PubMed]

12. Blount, K.F.; Zhao, F.; Hermann, T.; Tor, Y. Conformational constraint as a means for understanding RNA-aminoglycoside specificity. J. Am. Chem. Soc. 2005, 127, 9818-9829. [CrossRef] [PubMed]

13. Ryu, D.H.; Rando, R.R. Decoding region bubble size and aminoglycoside antibiotic binding. Bioorgan. Med. Chem. Lett. 2002, 12, 2241-2244. [CrossRef]

14. Litovchick, A.; Evdokimov, A.G.; Lapidot, A. Arginine-aminoglycoside conjugates that bind to HIV transactivation responsive element RNA in vitro. FEBS Lett. 1999, 445, 73-79. [CrossRef]

15. Borkow, G.; Lara, H.H.; Lapidot, A. Mutations in gp41 and gp120 of HIV-1 isolates resistant to hexa-arginine neomycin B conjugate. Biochem. Biophys. Res. Commun. 2003, 312, 1047-1052. [CrossRef]

16. Borkow, G.; Vijayabaskar, V.; Lara, H.H.; Kalinkovich, A.; Lapidot, A. Structure-activity relationship of neomycin, paromomycin, and neamine-arginine conjugates, targeting HIV-1 gp120-CXCR4 binding step. Antivir. Res. 2003, 60, 181-192. [CrossRef]

17. Cabrera, C.; Gutierrez, A.; Blanco, J.; Barretina, J.; Litovchick, A.; Lapidot, A.; Evdokimov, A.G.; Clotet, B.; Este, J.A. Anti-human immunodeficiency virus activity of novel aminoglycoside-arginine conjugates at early stages of infection. Aids Res. Hum. Retrovir. 2000, 16, 627-634. [CrossRef]

18. Cabrera, C.; Gutierrez, A.; Barretina, J.; Blanco, J.; Litovchick, A.; Lapidot, A.; Clotet, B.; Este, J.A. Anti-HIV activity of a novel aminoglycoside-arginine conjugate. Antivir. Res. 2002, 53, 1-8. [CrossRef]

19. Hartz, D.; McPheeters, D.S.; Gold, L. Selection of the initiator tRNA by Escherichia coli initiation factors. Genes Dev. 1989, 3, 1899-1912. [CrossRef]

20. Fosso, M.Y.; Zhu, H.; Green, K.D.; Garneau-Tsodikova, S.; Fredrick, K. Tobramycin Variants with Enhanced Ribosome-Targeting Activity. ChemBioChem 2015, 16, 1565-1570. [CrossRef]

21. Brautigam, C.A.; Steitz, T.A. Structural and functional insights provided by crystal structures of DNA polymerases and their substrate complexes. Curr. Opin. Struct. Biol. 1998, 8, 54-63. [CrossRef]

22. Doublie, S.; Tabor, S.; Long, A.M.; Richardson, C.C.; Ellenberger, T. Crystal structure of a bacteriophage T7 DNA replication complex at 2.2 A resolution. Nature 1998, 391, 251-258. [CrossRef] [PubMed]

23. Iyer, L.M.; Koonin, E.V.; Leipe, D.D.; Aravind, L. Origin and evolution of the archaeo-eukaryotic primase superfamily and related palm-domain proteins: Structural insights and new members. Nucleic Acids Res. 2005, 33, 3875-3896. [CrossRef] [PubMed]

24. Jeruzalmi, D.; Steitz, T.A. Structure of T7 RNA polymerase complexed to the transcriptional inhibitor T7 lysozyme. EMBO J. 1998, 17, 4101-4113. [CrossRef]

25. Reuman, E.C.; Rhee, S.Y.; Holmes, S.P.; Shafer, R.W. Constrained patterns of covariation and clustering of HIV-1 non-nucleoside reverse transcriptase inhibitor resistance mutations. J. Antimicrob. Chemother. 2010, 65, 1477-1485. [CrossRef]

26. Xi, H.; Davis, E.; Ranjan, N.; Xue, L.; Hyde-Volpe, D.; Arya, D.P. Thermodynamics of nucleic acid "shape readout" by an aminosugar. Biochemistry 2011, 50, 9088-9113. [CrossRef]

27. Sainlos, M.; Hauchecorne, M.; Oudrhiri, N.; Zertal-Zidani, S.; Aissaoui, A.; Vigneron, J.P.; Lehn, J.M.; Lehn, P. Kanamycin A-derived cationic lipids as vectors for gene transfection. ChemBioChem 2005, 6, 1023-1033. [CrossRef]

28. Habrant, D.; Peuziat, P.; Colombani, T.; Dallet, L.; Gehin, J.; Goudeau, E.; Evrard, B.; Lambert, O.; Haudebourg, T.; Pitard, B. Design of Ionizable Lipids To Overcome the Limiting Step of Endosomal Escape: Application in the Intracellular Delivery of mRNA, DNA, and siRNA. J. Med. Chem. 2016, 59, 3046-3062. [CrossRef] 
29. Desigaux, L.; Sainlos, M.; Lambert, O.; Chevre, R.; Letrou-Bonneval, E.; Vigneron, J.P.; Lehn, P.; Lehn, J.M.; Pitard, B. Self-assembled lamellar complexes of siRNA with lipidic aminoglycoside derivatives promote efficient siRNA delivery and interference. Proc. Natl. Acad. Sci. USA 2007, 104, 16534-16539. [CrossRef]

30. Hou, E.W.; Prasad, R.; Beard, W.A.; Wilson, S.H. High-level expression and purification of untagged and histidine-tagged HIV-1 reverse transcriptase. Protein Expr. Purif. 2004, 34, 75-86. [CrossRef]

31. Shoji, S.; Walker, S.E.; Fredrick, K. Reverse translocation of tRNA in the ribosome. Mol. Cell 2006, 24, 931-942. [CrossRef] [PubMed]

32. Herzog, I.M.; Green, K.D.; Berkov-Zrihen, Y.; Feldman, M.; Vidavski, R.R.; Eldar-Boock, A.; Satchi-Fainaro, R.; Eldar, A.; Garneau-Tsodikova, S.; Fridman, M. 6"-Thioether tobramycin analogues: Towards selective targeting of bacterial membranes. Angew. Chem. Int. Ed. 2012, 51, 5652-5656. [CrossRef] [PubMed]

(C) 2020 by the authors. Licensee MDPI, Basel, Switzerland. This article is an open access article distributed under the terms and conditions of the Creative Commons Attribution (CC BY) license (http://creativecommons.org/licenses/by/4.0/). 